\title{
Analisis determinan keputusan nasabah menabung pada Bank Pembangunan Daerah Jambi (Studi kasus pegawai negeri sipil Kota Jambi)
}

\author{
Justia Lilia Sari Putri*; Heriberta; Emilia \\ Prodi Ekonomi Pembangunnan, Fak. Ekonomi dan Bisnis, Universitas Jambi \\ *E-mail korespondensi: justialsp@gmai.com
}

\begin{abstract}
Abstrack
This study aims to determine the characteristics of Jambi Regional Development Bank customers and to analyze the determinants of customer decisions to save at the Jambi Regional Development Bank, a case study of civil servants in Jambi City. This study uses data collection techniques through questionnaires distributed online, with a sampling technique that is simple random sampling with quantitative descriptive research methods and analyzed using binary logistic regression models through the SPSS program. The sample is Jambi city civil servants as many as 99 respondents. This study indicates that the variables of income and education have no positive and significant effect on the customer's decision to save. While the civil servant class variables were divided into two using a dummy variable namely, civil servant class III had no significant effect. In contrast, class IV civil servant had a positive and significant impact on customer saving decisions. And the age variable has a positive and significant impact, and the number of family dependents has a negative and significant effect on the customer's decision to save.
\end{abstract}

Keywords: Customer decision, Age, Number of dependents

\begin{abstract}
Abstrak
Penelitian ini bertujuan untuk mengetahui karakteristik nasabah Bank Pembangunan Daerah Jambi dan untuk menganalisis determinan keputusan nasabah menabung pada Bank Pembangunan Daerah Jambi studi kasus pegawai negeri sipil Kota Jambi. Penelitian ini menggunakan teknik pengumpulan data melalui kuesioner yang disebar secara online, dengan teknik pengambilan sampel yaitu sampling acak sederhana dengan metode penelitian deskriptif kuantitatif dan dianalisis menggunakan regresi model binary logistik melalui program SPSS. Sampelnya adalah pegawai negeri sipil kota Jambi sebanyak 99 responden. Hasil penelitian ini menunjukkan bahwa variabel pendapatan, dan pendidikan tidak berpengaruh positif dan signifikan terhadap keputusan nasabah menabung. Sedangkan variabel golongan PNS dibagi menjadi dua menggunakan variabel dummy, yaitu PNS golongan III tidak berpengaruh signifikan, sedangkan pada PNS golongan IV berpengaruh positif dan signifikan terhadap keputusan nasabah menabung. Serta variabel usia berpengaruh positif dan signifikan, dan untuk variabel jumlah tanggungan keluarga berpengaruh negatif dan signifikan terhadap keputusan nasabah menabung.
\end{abstract}

Kata kunci: Keputusan nasabah, Usia, Jumlah tanggungan keluarga

PENDAHULUAN

Dewasa ini industri perbankan sangat penting dalam mendorong pembangunan perekonomian suatu negara sangatlah besar. Hampir semua sektor yang berhubungan dengan kegiatan keuangan selalu membutuhkan layananperbankan. Dari kehidupan 
sehari-hari masyarakat ini dapat dilihat bahwa lembanga keuangan selalu dilibatkan, antara lain: menabung, transfer dana, transaksi pembayaran, dan lain sebagainya.

Pada era perdagangan bebas saat ini, perusahaan perlu mencari dan membangun sistem manajemen yang dapat mempertahankan pelanggan secara profesional. Hal yang menjadi pertimbangan utama perusahaan dalam melakukan retensi pelanggan, yang pertama karena biaya untuk mendapatkan pelanggan baru dalam lingkungan yang semakin kompetitif, dan yang kedua adalah bahwa probabilitas perusahaan berbanding lurus dengan pertumbuhan hubungan antara perusahaan dan pelanggannya bersfat tetap (Hurriyati, 2010).

Menurut UU Perbankan No. 10 Tahun 1998 tentang perbankan, bank merupakan badan usaha yang menghimpun dana dari masyarakat dalam bentuk simpanan dan menyalurkannya kembali kepada masyarakat dalam bentuk kredit atau bentuk-bentuk lainnya dalam rangka meningkatkan taraf hidup orang banyak. Bank umum adalah bank yang melaksanakan kegiatan usaha secara konvensional dan atau berdasarkan prinsip syariah, yang dalam kegiatannya memberikan jasa lalu lintas pembayaran.

Bank Indonesia telah menetapkan peraturan-peraturan yang salah satu diantaranya tertuang dalam Arsitektur Perbankan Indonesia (API) yang wajib bagi setiap bank (Ghulam, 2011). Dengan dibuatnya peraturan bank Indonesia maka perbankan akan mencapai visinya yang sehat, kuat dan efisien. Perbankan di Indonesia telah banyak yang beroperasi salah satunya Bank Pembangunan Daerah (BPD).

Bank Pembangunan Daerah (BPD) Merupakan salah satu badan usaha milik daerah yang bertugas mengembangkan perekonomian dan menggerakkan pembangunan daerah melalui kegiatanya sebagai bank. BPD memiliki peran strategis dalam mendorong perokonomian daerah dan wilayah operasional BPD (Hamudy, 2013).

Perkembangan Bank Pembangunan Daerah di Indonesia pada Agustus 2020 secara year on year (YoY), BPD mencatat pertumbuhan kredit sebesar 6,86 persen pada bulan agustus 2020. Jauh lebih tinggi dari pertumbuhan kredit secara industri yakni 1,04 persen. Sementara bank BUMN hanya tumbuh 3,05 persen, bank, bank swasta nasional (BUSN) devisa tahun 1,76 persen, bank campuran tumbuh 0,9 persen dan bank asing turun 5,12 persen. Secara year to date (ytd) atau dibanding akhir tahun 2019, kredit BPD juga tumbuh sebesar 1,7 persen. Sedangkan bank BUMN saja masih turun 0,88 persen.

Dalam statistik perbankan yang berada di Provinsi Jambi, perkembangan jumlah kantor perbankan yang berada di provinsi Jambi mencapai 61 kantor bank. Sedangkan di Kota Jambi terdapat 31 kantor, dan Bank Pembangunan Daerah Jambi memiliki 1 kantor pusat dengan 12 kantor cabang yang tersebar di Provinsi Jambi. Dengan jumlah penabung pada tahun 2015 sebagaimana tercantum dalam tabel 1:

Tabel 1. Jumlah penabung pada perbankan di provinsi Jambi (2015)

\begin{tabular}{lcc}
\hline \multicolumn{1}{c}{ Bank } & Jumlah Penabung & Persentase (\%) \\
\hline Bank Rakyat Indonesia (BRI) & 35.403 & 38 \\
Bank Negara Indonesia (BNI) & 19.675 & 21 \\
Bank Mandiri & 17.858 & 19 \\
BPD Jambi & 20.683 & 22 \\
\hline Total & $\mathbf{9 3 . 6 1 9}$ & $\mathbf{1 0 0}$ \\
\hline
\end{tabular}

Sumber: Badan Pusat Statistik Jambi 2021(diolah)

Berdasarkan data diatas, diketahui nasabah Bank Pembangunan Daerah Jambi sebanyak 20.628 penabung atau 22 persen, artinya jumlah nasabah Bank Pembangunan Daerah Jambi lebih banyak nasabahnya kedua setelah Bank Rakyat Indonesia (BRI) 
yaitu sebesar 38 persen. Dengan melihat hal ini maka Bank Pembangunan Daerah Jambi memiliki daya saing yang ketat. Prospek industri perbankan yang semakin meningkat menuntut lembaga perbankan memiliki strategi yang tepat dalam memasarkan produknya.

Bank Pembangunan Daerah Jambi setiap tahunnya cenderung mengalami kenaikan, jika dilihat dari Total Asset yang dimilikinya sebesar Rp. 11.716 miliar pada tahun 2019, meningkat sebesar 0,07 persen dibandingkan tahun sebelumnya yaitu sebesar Rp. 10.895 miliar pada tahun 2018.

Tabel 2. Dana pihak ketiga Bank Pembangunan Daerah jambi 2016-2019 (dalam jutaan rupiah)

\begin{tabular}{lcccccccc}
\hline \multirow{2}{*}{ Tahun } & \multicolumn{2}{c}{ Dana Pihak Ke 3 } & \multicolumn{2}{c}{ Giro } & \multicolumn{2}{c}{ Tabungan } & \multicolumn{2}{c}{ Deposito } \\
\cline { 2 - 9 } & $\sum(\mathbf{R p})$ & $\mathbf{G ( \% )}$ & $\sum(\mathbf{R p )}$ & $\mathbf{G ( \% )}$ & $\sum(\mathbf{R p )}$ & $\mathbf{G ( \% )}$ & $\sum(\mathbf{R p})$ & $\mathbf{G ( \% )}$ \\
\hline 2016 & 4.333 .739 & 0,14 & 1.025 .495 & 0,39 & 824.290 & 0,13 & 2.483 .954 & 0,07 \\
2017 & 5.729 .482 & 0,32 & 1.398 .731 & 0,36 & 1.092 .783 & 0,32 & 3.237 .968 & 0,30 \\
2018 & 6.835 .751 & 0,19 & 1.630 .372 & 0,16 & 1.400 .645 & 0,28 & 3.804 .734 & 0,17 \\
2019 & 7.708 .677 & 0,12 & 2.300 .751 & 0,41 & 1.697 .850 & 0,21 & 3.710 .076 & $-0,02$ \\
\hline
\end{tabular}

Sumber: Annual Report Bank Pembangunan Daerah Jambi, 2021

Dilihat dari jumlah dana pihak ketiga (giro, tabungan deposito) selama 4 tahun terakhir dana pihak ketiga selalu mengalami kenaikan dari tahun ketahun. Pada tahun 2016 dana pihak ketiga sebesar Rp. 4.333 miliar dan terus meningkat sebesar 0,14 persen pada tahun 2016. Dan terus melaju naik sampai tahun 2019 sebesar Rp. 7.708 miliar. Dan masih didominasi oleh deposito dan diikuti oleh giro dan tabungan, artinya masyarakat Kota Jambi masih cenderung untuk melakukan simpanan dalam jangka panjang.

Menurut Sumitro (1990), menjelaskan bahwa pendapatan adalah penghasilan yang diterima dan diberikan kepada pelaku ekonomi berdasarkan prestasi-prestasi yang dilakukan yaitu berupa pendapatan dari profesi yang dilakukan sendiri atau usaha peorangan dan pendapatan dari kekayaan.

Selain pendapatan, ada juga Usia. Biasanya semakin bertambahnya usia seseorang semakin matang pula pemikiran mereka. Menurut Nuswantari (1998) usia diartikan dengan lamanya keberadaan seseorang diukur dalam satuan waktu di pandang dari segi kronologik, indiviu normal yang memperlihatkan derajat perkembangan anatomis dan fisologik sama.

Selain itu pendidikan merupakan faktor individual (pribadi), yang mempengaruhi pengambilan keputusan. Pendidikan akan mempengaruhi pola berfikir seseorang dalam menyikapi suatu permasalahan. Menurut Ikhsan (2003) pendidikan dalam pengertian yang sederhana dan umum adalah usaha manusia untuk menumbuhkan dan mengembangkan potensi-potensi baik jasmani maupun rohani sesuai dengan nilai-nilai yang ada didalam masyarakat yang berbudaya.

Secara umum para nasabah yang akan menabung tentu memilih bank yang dapat memberikan keuntungan dan efisiensi. Dalam hal ini terdapat banyak aspek yang harus dipertimbangkan. Pandangan masyarakat terhadap suatu bank juga menjadi hal penting. Penting bagi nasabah untuk memutuskan suatu keputusan menabung.

Diantara berbagai golongan kelompok maupun profesi, Pegawai Negeri Sipil (PNS) merupakan salah satu golongan yang menjadi nasabah di Bank Pembangunan Daerah Jambi. Dari tingkat pendidikan pegawai negeri sipil adalah golongan masyarakat yang bisa dikategorikan cukup. Sedangkan dari sisi tingkat pendapatan pegawai negeri sipil dapat dikategorikan berada pada posisi kelas menengah. Apresiasi 
yang tinggi patut diberikan kepada para PNS yang menjadi nasabah Bank Pembangunan Daerah Jambi, mengingat sekarang para PNS diwajibkan membuka rekening bank daerah, tak terkecuali Bank Pembangunan Daerah Provinsi Jambi.

Dengan melihat kondisi diatas penulis tertarik untuk meneliti mengenai determinan yang dapat mempengaruhi keputusan nasabah menabung pada Bank Pembangunan Daerah Jambi karena penelitian mengenai Bank Pembangunan Daerah Jambi telah banyak dilakukan oleh mahasiswa maupun para pendidik. Namun, penulis meyakini bahwa hampir tidak ada penelitian yang mengangkat mengenai analisis determinan yang mempengaruhi minat menabung nasabah pada Bank Pembangunan Daerah Jambi. Bank Pembangunan Daerah Jambi merupakan BPD yang masih harus selalu di perhatikan persaingan dan reputasinya di masyarakat untuk selalu di evaluasi segala kekurangannya. Hal tersebut akan terwujud atas rekomendasi melalui berbagai cara, salah satunya dengan penelitian yang penulis lakukan seperti halnya penelitian ini.

Berdasarkan paparan yang ada diatas maka peneliti tertarik untuk melakukan penelitian Mengenai "analisis determinan keputusan nasabah menabung pada Bank Pembangunan Daerah jambi (studi kasus pegawai negeri sipil kota jambi)”.

\section{METODE}

\section{Jenis dan sumber data}

Data yang digunakan dalam penelitian ini adalah data primer dan data sekunder. Teknik pengumnpulan data pada penelitian ini menggunakan teknik sampling acak sederhana. Populasi dari penelitian ini adalah pegawi negeri sipil kota jambi yang mana berjumlah 6001 orang, dan dengan sampel sebanyak 99 responden yang dihitung dengan menggunakan rumus slovin.

\section{metode analisis data}

metode analisis dalam peneltian ini adalah metode deskriptif dengan pendekatan kuantitatif. analisis deskriptif adalah suatu metode yang berfungsi untuk membuat gambaran sistematis dan faktual mengenai fakta-fakta yang ada dilapangan dengan berdasarkan kepada teori-teori, konsep-konsep, yang ada di literatur yang terkait dengan penelitian ini. dimana prosedur gejala dan hubungan-hubunganya definisikan, diklasifikasikan dan dikategorikan. sedangkan analisis kuantitatif adalah metode penelitian yang menggunakan proses data-data yang berupa angka sebagai alat menganalisis dan melakukan kajian penelitian, terutama mengenai apa yang sudah di teliti (amri, 2009).

model analisis statistik yang digunakan adalah metode logistic regression atau analisis model logistic (logit). model regresi logistik biner digunakan untuk menganalisa hubungan antara satu variabel respon (variabel tak bebas) dan beberapa variabel bebas, dengan variabel responnya berupa data yaitu bernilai 1 untuk menyatakan keberadaan sebuah karakteristik dan bernilai 0 untuk menyatakan ketidakberadan sebuah karakteristik (agresti, 2007). dengan persamaan sebagai berikut:

keputusan menabung $=f$ (pendapatan, usia, pendidikan, golongan pns, jumlah tanggungan keluarga)

Dengan persamaan model regresi Logit: 
$\mathrm{KM}\left(\frac{P i}{1-P i}\right)=Z i=\beta_{0}+\beta_{1} \mathrm{Pd}+\beta_{2} \mathrm{U}+\beta_{3} \mathrm{PDDK}+\beta_{4} \mathrm{DK} 1+\beta_{5} \mathrm{DK} 2+\beta_{6} \mathrm{JT}+\mathrm{e}$

Keterangan:

$\mathrm{KM}=$ Keputusan nasabah menabung (dengan Variabel dummy 1 menabung dan 0 tidak menabung)

$\beta=$ Koefisien regresi

$\mathrm{Pd} \quad=$ Pendapatan

$\mathrm{U} \quad=$ Usia

PDDK = Pendidikan

Dk1 = Golongan PNS (dengan variabel dummy 1 jika golongan III, 0 jika lainnya)

Dk2 = Golongan PNS (dengan variabel dummy 1 jika golongan IV, 0 jika lainnya)

Dk1 $=0, \mathrm{Dk} 2=0$ merupakan golongan II

Dk1 $=0, \mathrm{Dk} 2=1$ merupakan golongan III

Dk1 $=1, \mathrm{Dk} 2=0$ merupakan golongan IV

JT = Jumlah tanggungan keluarga

e $\quad=$ kesalahan (standard error)

\section{HASIL DAN PEMBAHASAN}

\section{Karakteristik responden}

Setiap responden memiliki karakteristik yang berbeda. Untuk itu perlu dilakukan penelitian pengelompokan dengan karakteristik tertentu. Adapun yang digunakan dalam penelitian ini adalah kategori Status Menabung, Jenis Kelamin, Usia, status perkawinan, Golongan PNS, pendidikan terakhir, jumlah pendapatan dan jumlah tanggungan. Sampel yang digunakan dalam penelitian ini sebanyak 99 Pegawai Negeri Sipil yang menjadi nasabah dan berdomisili di Kota Jambi yang telah menabung di Bank Pembangunan Daerah Jambi.

\section{Karakteristik responden berdasarkan status menabung}

Responden yang terpilih dikelompokkan berdasarkan status menabung atau tidak menabung di Bank Pembangunan Daerah Jambi. Untuk mengetahui proporsi status menabung dan tidak dengan jelas dapat dilihat pada Tabel 1 berikut:

Tabel 1. Karakteristik responden berdasarkan status menabung

\begin{tabular}{llcc}
\hline No. & Status menabung & Jumlah responden & Persentase (\%) \\
\hline 1. & Menabung & 55 & 56 \\
2. & Tidak menabung & 44 & 44 \\
\hline & Jumlah & $\mathbf{9 9}$ & $\mathbf{1 0 0}$
\end{tabular}

Sumber: data diolah, 2021

Dari tabel diatas dapat dilihat bahwa persentase jumlah responden yang menabung sebanyak 55 orang atau 56 persen, dan responden yang tidak menabung sebesar 44 orang atau 44 persen dari keseluruhan responden.

\section{Karakteristik responden berdasarkan jenis kelamin}

Responden yang terpilih dikelompokkan berdasarkan jenis kelamin dalam dua kelompok yaitu untuk laki-laki dan perempuan. Untuk mengetahui proporsi jenis kelamin dengan jelas dapat dilihat pada tabel 2 berikut: 
Tabel 2. Karakteristik responden berdasarkan jenis kelamin

\begin{tabular}{llcccc}
\hline \multirow{2}{*}{ No } & \multirow{2}{*}{ Jenis Kelamin } & \multicolumn{3}{c}{ Jumlah } & \multirow{2}{*}{ Persentase (\%) } \\
\cline { 3 - 5 } & & Menabung & Tidak & Total & 55 \\
\hline 1. & Laki-laki & 33 & 21 & 54 & \\
& Persentase (\%) & 61 & 39 & & 45 \\
2. & Perempuan & 22 & 23 & 45 & \\
& Persentase (\%) & 49 & 51 & & 100 \\
& Jumlah & 55 & 44 & 99 & \\
\hline
\end{tabular}

Sumber: data diolah, 2021

Dari Tabel 2, dapat kita lihat bahwa persentase jumlah responden dengan jenis kelamin laki-laki berjumlah 54 atau 55 persen dengan jumlah laki-laki yang menabung sebesar 61 persen, dan yang tidak menabung sebesar 39 persen. Sedangkan jumlah reponden dengan jenis kelamin perempuan berjumlah 45 atau 45 persen dengan jumlah yang menabung sebanyak49 persen dan perempuan yang tidak menabung lebih mendominasi yaitu sebesar 51 persen. Dengan persentase tersebut diharapkan semua jenis kelamin reponden sudah terwakili atau digunakan datanya dalam penelitian.

\section{Karakteristik responden berdasarkan usia}

Responden dikelompokkan menjadi 4 kelompok yaitu, 26-35 tahun, 36-45 tahun, 46-55 tahun, dan >55 tahun. Untuk mengetahui proporsi usia dengan jelas dapat dilihat pada tabel 3 dibawah ini.

Tabel 3. Karakteristik responden berdasarkan usia

\begin{tabular}{|c|c|c|c|c|c|c|c|}
\hline \multirow{3}{*}{ No. } & \multirow{3}{*}{ Umur Responden } & \multicolumn{5}{|c|}{ Jumlah Responden } & \multirow{3}{*}{$\begin{array}{c}\text { Persentase } \\
(\%)\end{array}$} \\
\hline & & \multicolumn{2}{|c|}{ Menabung } & \multicolumn{2}{|c|}{ Tidak } & \multirow[b]{2}{*}{ Total } & \\
\hline & & $\mathbf{L}$ & $\mathbf{P}$ & $\mathbf{L}$ & $\mathbf{P}$ & & \\
\hline \multirow[t]{2}{*}{1.} & $26-35$ & 11 & 8 & 9 & 16 & 44 & 44 \\
\hline & Persentase (\%) & 25 & 18 & 20 & 36 & & \\
\hline \multirow[t]{2}{*}{2.} & $36-45$ & 19 & 6 & 6 & 5 & 36 & 36 \\
\hline & Persentase (\%) & 53 & 17 & 17 & 14 & & \\
\hline \multirow[t]{2}{*}{3.} & $46-55$ & 3 & 6 & 6 & 2 & 17 & 17 \\
\hline & Persentase (\%) & 18 & 35 & 35 & 12 & & \\
\hline \multirow[t]{3}{*}{4.} & $>55$ & 0 & 2 & 0 & 0 & 2 & 2 \\
\hline & Persentase $(\%)$ & 0 & 100 & 0 & 0 & & \\
\hline & Jumlah & 33 & 22 & 21 & 23 & 99 & 100 \\
\hline
\end{tabular}

Sumber: Data diolah, 2021

Berdasarkan Tabel 3, maka dapat dilihat responden dari kelompok 26-35 tahun sebanyak 44 orang atau 44 persen dengan jumlah laki-laki menabung sebesar 25 persen, serta pada perempuan sebesar 18 persen. sedangkan perempuan lebih banyak yang tidak menabung sebesar 36 persen dan laki-laki sebesar 20 persen. Artinya pada usia 26-35 tahun laki-laki suka menabung pada Bank Pembangunan Daerah Jambi sedangkan perempuan tidak.

Kelompok responden dengan usia 36-45 tahun sebanyak 36 orang atau 36 persen dengan di dominasi laki-laki menabung sebesar 53 persen, sedangkan perempuan 17 
persen. Artinya pada usia 36-45 tahun laki-laki banyak yang memilih menabung di Bank Pembangunan Daerah Jambi.

Kelompok responden dengan usia 46-55 tahun sebanyak 17 orang atau 17 persen dengan jumlah laki-laki yang menabung sebesar 18 persen, perempuan 35 persen, dan laki-laki yang tidak menabung sebesar 35 persen, serta perempuan hanya 12 persen. Selanjutnya kelompok usia $>55$ tahun jumlah responden sebanyak 2 orang atau 2 persen dengan jumlah perempuan menabung sebesar 2 persen, sedangkan yang lainnya 0 . Artinya pada usia 46-55 dan usia >55 banyak responden yang lebih memilih menabung pada bank pemerintah ataupun bank swasta, dan responden yang mendominasi pada usia 26-35 tahun dibandingkan dengan kelompok usia lainnya.

\section{Karakteristik responden berdasarkan status perkawinan}

Berdasarkan responden yang terpilih dikelompokkan berdasarkan status perkawinan responden, dapat diketahui kelompok responden yaitu, belum menikah, menikah dan Cerai. Adapun jumlah responden dan persentase dari setiap responden yang berdasarkan status perkawinan dapat dilihat pada tabel dibawah ini.

Tabel 4. Karakteristik responden berdasarkan status perkawinan

\begin{tabular}{|c|c|c|c|c|c|c|c|}
\hline \multirow{3}{*}{ No. } & \multirow{3}{*}{$\begin{array}{c}\text { Status } \\
\text { Perkawinan }\end{array}$} & \multicolumn{5}{|c|}{ Jumlah Responden } & \multirow{3}{*}{$\begin{array}{c}\text { Persentase } \\
(\%)\end{array}$} \\
\hline & & \multicolumn{2}{|c|}{ Menabung } & \multicolumn{2}{|c|}{ Tidak } & \multirow{2}{*}{ Total } & \\
\hline & & $\mathbf{L}$ & $\mathbf{P}$ & $\mathbf{L}$ & $\mathbf{P}$ & & \\
\hline \multirow[t]{2}{*}{1.} & Belum Menikah & 5 & 5 & 3 & 10 & 23 & 23 \\
\hline & Persentase (\%) & 22 & 22 & 13 & 43 & & \\
\hline \multirow[t]{2}{*}{2.} & Menikah & 27 & 16 & 16 & 13 & 72 & 73 \\
\hline & Persentase $(\%)$ & 38 & 22 & 22 & 18 & & \\
\hline \multirow[t]{3}{*}{3.} & Cerai & 1 & 1 & 2 & 0 & 4 & 4 \\
\hline & Persentase $(\%)$ & 25 & 25 & 50 & 0 & & \\
\hline & Jumlah & 33 & 22 & 21 & 23 & 99 & 100 \\
\hline
\end{tabular}

Sumber: Data diolah, 2021

Berdasarkan dari Tabel 4 dapat dilihat bahwa status perkawinan responden terbesar adalah menikah dengan persentase 73 persen dengan jumlah laki-laki yang menabung sebesar 38 persen dan perempuan 22 persen, serta yang tidak menabung sebesar 22 persen dan perempuan 18 persen. Responden yang belum menikah sebesar 23 persen dengan jumlah laki-laki dan perempuan yang menabung masing-masing dengan angka 22 persen dan yang laki-laki tidak menabung sebesar 13 persen, sedangkan perempuan sebesar 43 persen. Pada status perkawinan belum menikah lebih banyak wanita yang tidak menabung. Selain itu responden memiliki status pernikahan cerai sebesar 4 persen dengan jumlah laki-laki dan perempuan yang menabung masingmasing dengan angka 25 persen, serta yang tidak menabung laki-laki 2, perempuan 0 . Dari hasil penelitian dapat diketahui bahwa rata-rata Pegawai Negeri Sipil Kota Jambi yang menabung di Bank Pembangunan Daerah Jambi telah menikah.

\section{Karakteristik responden berdasarkan golongan PNS}

Berdasarkan hasil penelitian yang dilakukan, Golongan Pegawai Negeri Sipil (PNS) dari responden dapat dilihat pada tabel 5 dibawah ini: 
Tabel 5. Karakteristik responden berdasarkan golongann PNS

\begin{tabular}{|c|c|c|c|c|c|c|c|}
\hline \multirow{3}{*}{ No. } & \multirow{3}{*}{ Golongan PNS } & \multicolumn{5}{|c|}{ Jumlah Responden } & \multirow{3}{*}{$\begin{array}{c}\text { Persentase } \\
(\%)\end{array}$} \\
\hline & & \multicolumn{2}{|c|}{ Menabung } & \multicolumn{2}{|c|}{ Tidak } & \multirow{2}{*}{ Total } & \\
\hline & & $\mathbf{L}$ & $\mathbf{P}$ & $\mathbf{L}$ & $\mathbf{P}$ & & \\
\hline \multirow[t]{2}{*}{1.} & II & 4 & 3 & 4 & 3 & 14 & 14 \\
\hline & Persentase (\%) & 29 & 21 & 29 & 21 & & \\
\hline \multirow[t]{2}{*}{2.} & III & 18 & 13 & 13 & 20 & 64 & 65 \\
\hline & Persentase (\%) & 28 & 20 & 20 & 31 & & \\
\hline \multirow[t]{3}{*}{3.} & IV & 11 & 6 & 4 & 0 & 21 & 21 \\
\hline & Persentase $(\%)$ & 52 & 29 & 19 & 0 & & \\
\hline & Jumlah & 33 & 22 & 21 & 23 & 99 & 100 \\
\hline
\end{tabular}

Sumber: data diolah, 2021

Berdasarkan Tabel 5 dapat diketahui bahwa golongan PNS dari seluruh responden golongan II sebanyak 14 responden atau 14 persen dengan jumlah laki-laki yang menabung sebesar 29 persen dan perempuan sebesar 21 persen, serta yang tidak menabung laki-laki sebesar 29 persen dan perempuan 21 persen, pada golongan III sebanyak 64 responden atau 65 persen, dengan jumlah laki-laki yang menabung sebesar 28 persen dan perempuan 20 persen, serta laki-laki-laki yang tidak menabung sebesar 20 persen dan perempuan 21 persen. Artinya pada golongan III laki-laki lebih cenderung suka menabung di Bank Pembangunan Daerah Jambi sedangkan perempuan tidak.

Golongan IV sebanyak 21 responden atau 21 persen dengan jumlah laki-laki yang menabung 52 persen dan perempuan 26 persen, serta yang tidak menabung laki-laki 19 persen sementara perempuan 0 , artinya bahwa laki-laki dan perempuan pada golongan IV sama-sama lebih suka menabung di Bank Pembangunan Daerah . Dari hasil tersebut dapat disimpulkan bahwa mayoritas dari responden pada penelitian ini adalah pada golongan III yaitu sebesar 64 responden.

\section{Karakteristik responden berdasarkan pendidikan}

Berdasarkan hasil penelitian, pendidikan terakhir dari responden yang dapat dilihat pada tabel 6:

Tabel 6. Karakteristik responden berdasarkan pendidikan

\begin{tabular}{|c|c|c|c|c|c|c|c|}
\hline \multirow{3}{*}{ No. } & \multirow{3}{*}{$\begin{array}{c}\text { Tingkat } \\
\text { Pendidikan }\end{array}$} & \multicolumn{5}{|c|}{ Jumlah Responden } & \multirow{3}{*}{$\begin{array}{c}\text { Persentase } \\
(\%)\end{array}$} \\
\hline & & \multicolumn{2}{|c|}{ Menabung } & \multicolumn{2}{|c|}{ Tidak } & \multirow{2}{*}{ Total } & \\
\hline & & $\mathbf{L}$ & $\mathbf{P}$ & $\mathbf{L}$ & $\mathbf{P}$ & & \\
\hline \multirow[t]{2}{*}{1.} & SLTA & 6 & 1 & 7 & 9 & 23 & 23 \\
\hline & Persentase $(\%)$ & 26 & 4 & 30 & 39 & & \\
\hline \multirow[t]{2}{*}{2.} & Diploma & 8 & 5 & 4 & 4 & 21 & 21 \\
\hline & Persentase $(\%)$ & 38 & 24 & 19 & 19 & & \\
\hline \multirow[t]{2}{*}{3.} & Sarjana (S1) & 18 & 13 & 10 & 10 & 51 & 52 \\
\hline & Persentase $(\%)$ & 35 & 25 & 20 & 20 & & \\
\hline \multirow[t]{3}{*}{4.} & Pascasarjana (S2) & 1 & 3 & 0 & 0 & 4 & 4 \\
\hline & Persentase $(\%)$ & 25 & 75 & 0 & 0 & & \\
\hline & Jumlah & 33 & 22 & 21 & 23 & 99 & 100 \\
\hline
\end{tabular}

Sumber: Data diolah, 2021 
Diketahui responden pendidikan menunjukkan bahwa mayoritas responden adalah Sarjana (S1) sebesar 51 responden atau 52 persen dengan jumlah laki-laki yang menabung 35 persen dan perempuan 25 persen, serta laki-laki dan perempuan yang tidak menabung masing-masing dengan angka 20 persen. Kemudian sisanya berpendidikan SLTA (SMA) sebesar 23 responden atau 23 persen dengan jumlah lakilaki yang menabung 26 persen dan perempuan hanya 4 persen, serta laki-laki yang tidak menabung 30 persen dan perempuan 39 persen. Artinya bahwa pada tingkat pendidikan SLTA laki-laki suka menabung di Bank Pembangunan Daerah Jambi sedangkan perempuan tidak suka menabung di Bank Pembangunan Daerah Jambi.

Selanjutnya pada tingkat pendidikan diploma mimiliki 21 responden atau 21 persen, dengan jumlah laki-laki yang menabung 38 persen serta perempuan 24 persen, dan laki-laki dan perempuan yang tidak menabung masing-masing dengan angka 19 persen. Kemudian tingkat pendidikan pascasarjana (S2) sebanyak 4 responden atau 4 persen dengan laki-laki yang menabung 25 persen dan perempuan 75 persen, serta 0 untuk yang tidak menabung.

\section{Karakteristik responden berdasarkan jumlah pendapatan}

Pada penelitian ini penulis mengelompokkan responden berdasarkan jumlah pendapatan yang dapat dilihat dari tabel 7 dibawah ini:

Tabel 7. Karakteristik responden berdasarkan jumlah pendapatan

\begin{tabular}{|c|c|c|c|c|c|c|c|}
\hline \multirow{3}{*}{ No. } & \multirow{3}{*}{ Jumlah Pendapatan } & \multicolumn{5}{|c|}{ Jumlah Responden } & \multirow{3}{*}{$\begin{array}{c}\text { Persentase } \\
(\%)\end{array}$} \\
\hline & & \multicolumn{2}{|c|}{ Menabung } & \multicolumn{2}{|c|}{ Tidak } & \multirow{2}{*}{ Total } & \\
\hline & & $\mathbf{L}$ & $\mathbf{P}$ & $\mathbf{L}$ & $\mathbf{P}$ & & \\
\hline \multirow[t]{2}{*}{1.} & $2.000 .000-2.900 .000$ & 3 & 2 & 2 & 1 & 8 & 8 \\
\hline & persentase $(\%)$ & 38 & 25 & 25 & 13 & & \\
\hline \multirow[t]{2}{*}{2.} & $3.000 .000-3.900 .000$ & 17 & 9 & 11 & 20 & 57 & 58 \\
\hline & persentase $(\%)$ & 30 & 16 & 19 & 35 & & \\
\hline \multirow[t]{2}{*}{3.} & $4.000 .000-4.900 .000$ & 5 & 8 & 7 & 2 & 22 & 22 \\
\hline & persentase $(\%)$ & 23 & 36 & 32 & 9 & & \\
\hline \multirow[t]{3}{*}{4.} & $>5.000 .000$ & 8 & 3 & 1 & 0 & 12 & 12 \\
\hline & persentase $(\%)$ & 67 & 25 & 8 & 0 & & \\
\hline & Jumlah & 33 & 22 & 21 & 23 & 99 & 100 \\
\hline
\end{tabular}

Sumber: Data diolah, 2021

Keterangan pada Tabel 7 menunjukkan bahwa responden rata-rata memiliki pendapatan Rp. 2.000.000- 2.900.000 sebanyak 8 orang dengan persentase sebesar 8 persen dengan laki-laki yang menabung sebesar 38 persen, perempuan 25 persen, serta laki-laki yang tidak menabung sebesar 25 persen dan perempuan 13 persen. Selanjutnya pendapatan Rp. 3.000.000 - 3.900.000 sebanyak 57 orang dengan persentase sebesar 58 persen dengan laki-laki yang menabung sebesar 17 persen, perempuan 9 persen. Serta laki-laki yang tidak menabung 19 persen dan perempuan 20 persen. Artinya bahwa pada nasabah laki-laki yang memiliki pendapatan Rp 3.000.000 - 3.900.000 lebih suka menabung pada Bank Pembangunan Daerah Jambi sedangkan perempuan lebih banyak yang tidak menabung di Bank Pembangunan Daerah .

Selanjutnya pendapatan dengan kisaran Rp. 4.000.000 - 4.900 .000 sebanyak 22 orang atau 22 persen, dengan jumlah laki-laki yang menabung sebesar 23 persen, perempuan 36 persen. Sementara laki-laki yang tidak menabung sebesar 32 persen dan perempuan 9 persen, dan responden yang memiliki pendapatan Rp.>5.000.000 sebanyak 12 orang atau 12 persen dengan laki-laki yang menabung 67 persen, perempuan 25 
persen dan laki-laki yang tidak menabung 8 persen, dan perempuan 0 , artinya nasabah yang memiliki pada pendapatan Rp. $>5.000 .000$ baik laki-laki dan perempuan lebih suka menabung di Bank Pembangunan Daerah Jambi. Berdasarkan jumlah pendapatan seluruh responden dapat dihitung bahwa rata-rata pendapatan responden sebesar $\mathrm{Rp}$. 3.713.131

\section{Karakteristik responden berdasarkan jumlah tanggungan}

Karakteristik responden berdasarkan jumlah tanggungan yang dimiliki oleh responden merupakan jumlah orang atau keluarga yang dibiayai langsung oleh responden dimana orang tersebut tidak memiliki penghasilan seperti bapak, ibu, adik, anak, atau saudara. Jumlah tanggungan responden dapat dilihat melalui tabel 8 dibawah ini:

Tabel 8. Karakteristik responden berdasarkan jumlah tanggungan

\begin{tabular}{|c|c|c|c|c|c|c|c|}
\hline \multirow{3}{*}{ No. } & \multirow{3}{*}{$\begin{array}{c}\text { Tanggungan } \\
\text { Responden }\end{array}$} & \multicolumn{5}{|c|}{ Jumlah Responden } & \multirow{3}{*}{$\begin{array}{c}\text { Persentase } \\
(\%)\end{array}$} \\
\hline & & \multicolumn{2}{|c|}{ Menabung } & \multicolumn{2}{|c|}{ Tidak } & \multirow{2}{*}{ Total } & \\
\hline & & $\mathbf{L}$ & $\mathbf{P}$ & $\mathbf{L}$ & $\mathbf{P}$ & & \\
\hline \multirow[t]{2}{*}{1.} & 0 & 9 & 7 & 2 & 7 & 25 & 25 \\
\hline & persentase $(\%)$ & 36 & 28 & 8 & 28 & & \\
\hline \multirow[t]{2}{*}{2.} & 1 & 8 & 6 & 6 & 4 & 24 & 24 \\
\hline & persentase $(\%)$ & 33 & 25 & 25 & 17 & & \\
\hline \multirow[t]{2}{*}{3.} & 2 & 11 & 4 & 4 & 4 & 23 & 23 \\
\hline & persentase $(\%)$ & 48 & 17 & 17 & 17 & & \\
\hline \multirow[t]{2}{*}{4.} & 3 & 4 & 5 & 5 & 7 & 21 & 21 \\
\hline & persentase $(\%)$ & 19 & 24 & 24 & 33 & & \\
\hline \multirow[t]{3}{*}{5.} & 4 & 1 & 0 & 4 & 1 & 6 & 6 \\
\hline & persentase $(\%)$ & 17 & 0 & 67 & 17 & & \\
\hline & Jumlah & 33 & 22 & 21 & 23 & 99 & 100 \\
\hline
\end{tabular}

Sumber: Data diolah, 2021

Berdasarkan Tabel 8 dapat diketahui bahwa persentase dengan responden yang tidak memiliki tanggungan sebanyak 25 responden atau 25 persen dengan jumlah lakilaki yang menabung sebesar 36 persen dan perempuan 28 persen, serta yang laki-laki yang tidak menabung hanya 8 persen dan perempuan 28 persen. Kemudian responden dengan jumlah tanggungan 1 orang sebanyak 24 orang atau 24 persen dengan angka 33 persen untuk laki-laki, dan perempuan 25 persen. Serta laki-laki yang tidak menabung sebesar 25 persendan perempuan 17 persen.

Kemudian jumlah tanggungan 2 orang sebanyak 23 orang atau 23 persen dengan laki-laki yang menabung sebesar 48 persen dan perempuan 17 persen, sementara yang tidak menabung laki-laki dan perempuan memiliki masing-masing angka 17 persen. Jumlah tanggungan 3 orang sebanyak 21 orang atau 21 persen, dengan jumlah laki-laki yang menabung 19 persen dan perempuan 24 persen, lalu laki-laki yang tidak menabung sebesar 17 persen sedangkan perempuan 33 persen. Sementara jumlah tanggungan 4 orang dengan responden sebanyak 6 orangatau 6 persen dengan jumlah laki-laki yang menabung 17 persen, perempuan 0 persen, sementara laki-laki yang tidak menabung sebesar 67 persen dan perempuan 17 persen.

Dimana dapat kita lihat bahwa banyak dari para responden tidak memiliki tanggungan yaitu sebanyak 25 orang artinya semakin banyak jumlah tanggungan yang ada maka PNS Kota Jambi semakin enggan untuk menabung di Bank Pembangunan 
Daerah Jambi. Pada penelitian ini yang menjadi tanggungan responden merupakan orang tua, istri/suami, anak dan saudara.

\section{Hasil pengujian hipotesis}

Dalam penelitian ini Regresi Binnary Logit digunakan untuk melihat pengaruh pendapatan, usia, pendidikan, golongan PNS dan Jumlah Tanggungan keluarga terhadap keputusan nasabah menabung pada Bank Pembangunan Daerah Jambi di Kota. Berikut ini hasil dari metode analisa dan perhitungan yang dilakukan melalui program SPSS dengan tingkat signifikansi $\alpha=1 \%, 5 \%$ dan $10 \%$ :

Tabel 9. Classification Table

\begin{tabular}{|c|c|c|c|c|}
\hline \multicolumn{2}{|r|}{ Observed } & \multicolumn{3}{|c|}{ Predicted } \\
\hline & & \multicolumn{2}{|c|}{$\mathbf{K M}$} & \multirow{2}{*}{$\begin{array}{c}\text { Percentage } \\
\text { Correct }\end{array}$} \\
\hline & & Tidak menabung & menabung & \\
\hline Step & tidak menabung & 28 & 16 & 63,6 \\
\hline 1 & M Menabung & 16 & 39 & 70,9 \\
\hline & Overall Percentage & & & 67,7 \\
\hline
\end{tabular}

Sumber: Data diolah, 2021

Berdasarkan Tabel 9 Classification Tabel diatas bahwa jumlah sampel yang tidak menabung $28+16=44$ orang, dan yang benar-benar tidak menabung sebanyak 28 orang dan yang seharusnya tidak menabung namun menabung sebanyak 16 orang. Kemudian jumlah sampel yang menabung $16+39=55$ orang, dan yang benar-benarbenar menabung sebnayak 39 orang serta yang tidak menabung namun seharusnya menabung sebanyak 16 orang. Hasil interpretasi regresi logistik dengan SPSS maka diperoleh hasil Overall Percentage sebesar $(28+39) / 99=67,7$ persen yang berarti bahwa ketepatan model penelitian ini adalah sebesar 67,7

\section{Uji kelayakan model}

Berdasarkan pada Tabel 10 bahwa nilai Hosmer and Lemeshow Test diperoleh nilai Chi-Square sebesar 7,476 $<9,4877$ dengan tingkat sig. sebesar 0,486 >0,05, maka dapat dikatakan bahwa model fit atau diterima.

Tabel 10. Hosmer and Lemeshow Test

\begin{tabular}{lllllll}
\hline & Step & Chi-square & & Df & Sig. \\
\hline 1 & 7,476 & 5 & &, 486 & \\
\hline
\end{tabular}

Sumber: Data diolah, 2021

\section{Uji signifikansi dari parameter}

Hasil dari pengujian ini maka diperoleh persamaan Regresi Logit yang diperoleh sebagai berikut:

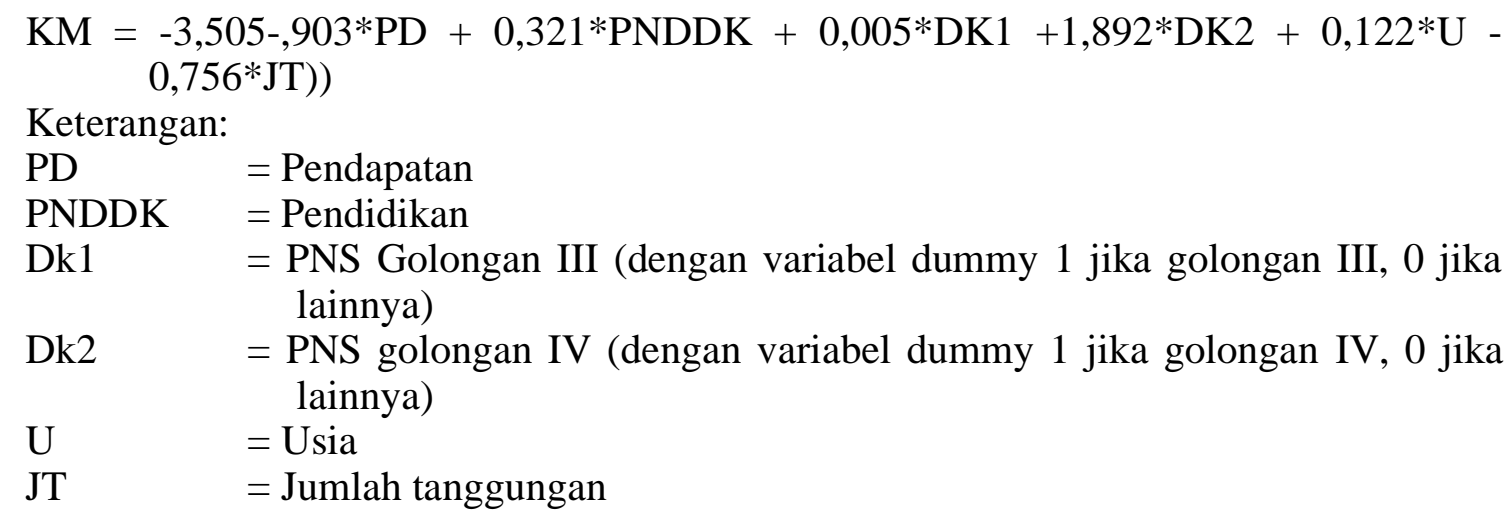


Tabel 3. Uji signifikansi dari parameter

\begin{tabular}{llrrrrrr}
\hline \multicolumn{7}{c}{ Variables in the Equation } \\
\hline & \multicolumn{1}{c}{ B } & \multicolumn{1}{c}{ S.E. } & Wald & Df & Sig. & \multirow{2}{*}{$\operatorname{Exp(B)}$} \\
\hline Step & PD &,- 903 &, 759 & 1,416 & 1 &, 234 &, 405 \\
$1^{\text {a }}$ & PNDDK &, 321 &, 496 &, 419 & 1 &, 517 & 1,379 \\
& DK1 &, 005 &, 661 &, 000 & 1 &, 995 &, 996 \\
& DK2 & 1,892 & 1,026 & 3,400 & 1 &, 065 & 6,632 \\
& U &, 122 &, 039 & 9,952 & 1 &, 002 & 1,130 \\
& JT &,- 756 &, 248 & 9,266 & 1 &, 002 &, 469 \\
& Constant & $-3,505$ & 1,343 & 6,817 & 1 &, 009 &, 030 \\
\hline
\end{tabular}

Sumber: Data diolah, 2021

\section{Pendapatan}

Berdasarkan hasil olahan data menunjukkan bahwa variabel pendapatan memiliki nilai $\operatorname{Exp}(B)$ sebesar 0,405 dengansig. 0,234> 0,05 maka variabel pendapatan tidak berpengaruh. Artinya bahwa PNS yang memiliki pendapatan lebih tinggi tidak mempengaruhi untuk menabung di Bank Pembangunan Daerah Jambi.

\section{Pendidikan}

Variabel pendidikan mempengaruhi Pegawai Negeri Sipil menabung di Bank Pembangunan Daerah Jambi dengan nilai $\operatorname{Exp}(B)$ sebesar 1,379. Variabel pendidikan memiliki nilai sig. sebesar 0,517>0,05 yang artinya variabel pendidikan tidak berpengaruh. Peluang Pegawai Negeri Sipil Menabung di Bank Pembangunan Daerah Jambi yang miliki pendidikan tinggi adalah sama dalam menabung dengan PNS yang bependidikan lebih rendah.

\section{PNS golongan III}

Variabel ini memiliki nilai $\operatorname{Exp(B)}$ sebesar 0,996. Dengan tingkat sig. sebesar $0,995>0,05$. Artinya bahwa PNS yang bergolongan III tidak berpengaruh signifikan terhadap keputusan nasabah menabung pada Bank Pembangunan Daerah Jambi.

\section{PNS golongan IV}

Berdasarkan pada hasil olah data diatas bahwa DK2 memiliki nilai Exp(B) sebesar 6,632, artinya bahwa peluang PNS golongann IV untuk memiliki tabungan adalah sebesar 6,632 kali dibandingkan dengan PNS golongan II. Dengan asumsi variabel pendapatan, pendidikan, usia dan jumlah tanggungan tetap. Dengan sig. sebesar 0,065 dengan tingkat signifikansi $10 \%$ maka variabel berpengaruh secara signifikan.

\section{Usia}

Variabel ini memiliki nilai $\operatorname{Exp(B)}$ sebesar 1,130, artinya bahwa PNS yang berusia lebih tua satu tahun peluang untuk menabung di Bank Pembangunan Daerah Jambi adalah 1,130 kali dibandingkan dengan PNS yang berusia lebih mudah (satu tahun), dengan asumsi pendapatan, pendidikan, golongan PNS dan jumlah tanggungan sama. Slope variabel ini sesuai dengan hipotesis yaitu positif dengan sig. 0,002 dengan tingkat signifikansi 5\% maka variabel ini berpengaruh secara signifikan.

\section{Jumlah tanggungan}

Variabel jumlah tanggungan memiliki nilai $\operatorname{Exp}(B)$ sebesar 0,469 artinya bahwa peluang PNS yang memiliki jumlah tanggungan lebih banyak dalam memutuskan menabung di Bank Pembangunan Daerah Jambi adalah 0,469 kali lebih kecil 
dibandingkan dengan PNS yang memiliki tanggungan sedikit. Sig.dalam variabel ini adalah 0.009 dengan tingkat signifikansi 5\% maka variabel ini berpengaruh secara signifikan.

\section{Pengaruh pendapatan terhadap keputusan nasabah menabung}

Hasil penelitian menunjukkan bahwa pendapatan tidak berpengaruh signifikan terhadap keputusan nasabah menabung di Bank Pembangunan Daerah Jambi. Dengan demikian hipotesis yang menyatakan bahwa pendapatan berpengaruh positif dan signifikan ditolak. Secara teori bahwa semakin meningkat jumlah pendapatan maka tabungan masyarakat pun akan meningkat. Namun, hasil dari penelitian ini sebaliknya. Semakin tinggi tingkat pendapatan nasabah, keputusan untuk menabung diBank Pembangunan Daerah Jambi semakin menurun. Hal ini dapat disebabkan karena semakin meningkatnya pendapatan nasabah lebih nyaman untuk menabung di bank yang lebih besar seperti bank BUMN ataupun bank swasta.

Sesuai dengan penelitian yang dilakukan oleh Arinal (2016) menyatakan bahwa dalam penelitian yang beliau lakukan pendapatan tidak berpengaruh signifikan terhadap keputusan nasabah menabung.

\section{Pengaruh pendidikan terhadap keputusan nasabah menabung}

Berdasarkan dari hasil penelitian ini dapat diketahui bahwa pendidikan tidak berpengaruh positif dan signifikan. Artinya semakin tinggi pendidikan terakhir seseorang tidak akan mempengaruhi keputusan nasabah untuk menabung di Bank Pembangunan Daerah Jambi. Hal ini tidak sesuai dengan teori yang diungkapkan oleh Keynes. Seseorang yang memiliki pendidikan lebih tinggi belum tentu lebih memiliki jasa perbankan daerah. Hal ini disebebkan oleh diasumsikan bahwa pendidikan memiliki keterkaitan dengan variabel pengetahuan terhadap perbankan daerah. Sesuai dengan penelitian yang lakukan oleh Arial (2016) yang menyatakan bahwa pendidikan tidak berpengaruh signifikan terhadap keputusan menjadi nasabah.

\section{Pengaruh golongan PNS terhadap keputusan nasabah menabung}

Dalam variabel golongan PNS peneliti membagi menjadi dua variabel yaitu DK1 dan DK2 dengan menggunakan variabel dummy. Berdasarkan penelitian ini dapat diketahui bahwa golongan PNS III berpengaruh positif dan tidak signifikan terhadap keputusan nasabah menabung di Bank Pembangunan Daerah Jambi. Sedangkan variabel DK2 (golongan PNS IV) berpengaruh positif dan signifikan terhadap keputusan nasabah menabung di Bank Pembangunan Daerah Jambi. Artinya PNS bergolongan IV lebih besar kesempatannya menabung di Bank Pembangunan Daerah Jambi di bandingkan dengan PNS golongan di bawahnya.

Sesuai dengan penelitian yang dilakukan oleh Lusiana Frida (2020) menyatakan bahwa PNS yang memiliki pangkat yang lebih tinggi cenderung menabung di bank. Secara logika bahwa golongan yang tinggi diikuti dengan pendapatan yang tinggi pula sehingga para PNS bergolongan IV mempunyai pendapatan yang lebih besar dibandingkan dengan PNS yang memiliki golongan dibawahnya. Hal inilah yang menyebabkan pada hasil regresi DK2 mendapatkan hasil berpengaruh signifikan. Sedangkan, pada DK1 tidak, karena PNS bergolongan III dan II memiliki kesempatan yang sama dalam menabung di Bank Pembangunan Daerah Jambi.

\section{Pengaruh usia terhadap keputusan nasabah menabung}

Dari hasil penelitian ini dapat diketahui bahwa usia berpengaruh secara positif dan signifikan dimana semakin tua usia PNS maka semakin besar kesempatan nasabah untuk menabung. Secara rasional bahwa semakin tinggi umur seseorang maka 
keinginan untuk menabung juga semakin besar, pola pikir yang dimiliki seseorang terhadap pengeluaran pendapatannya lebih cenderung memikirkan untuk jangka panjang dan masa depannya, akibatnya individu tersebut memilih menyisihkan uangnya untuk berjaga-jaga di masa yang akan datang jika terjadi sesuatu yang tidak terduga.

Sesuai dengan teori yang dikemukakan oleholeh Ando, Brumberg dan Modelini mengenaisiklus hidup bahwa variabel usia yang merupakan salah satu faktor sosial ekonomi yang mempengaruhi tingkat konsumsi masyarakt, dan pada usia produktif dimana tingkat konsumsi dan tabungan masyarakat tinggi.

\section{Pengaruh jumlah tanggungan terhadap keputusan nasabah menabung}

Berdasarkan penelitian ini dapat diketahui bahwa jumlah tanggungan berpengaruh negatif dan signifikan terhadap keputusan nasabah menabung. Artinya semakin banyak jumlah tanggungan yang dimiliki seseorang maka akan semakin kecil kemampuan seseorang untuk menabung. Sebaliknya jika semakin kecil jumlah tanggungan seseorang maka akan semakin besar kesempatannya untuk menabung. Hal tersebut disebabkan ketika seseorang memiliki jumlah tanggungan yang banyak maka pengeluaran untuk memenuhi kebutuhan rumah tangganya juga akan semakin besar, dan ketika jumlah tanggungan kecil maka pengeluarannya juga akan semakin kecil sehingga pendapatan yang dimiliki dapat disisihkan untuk menabung.

Sesuai dengan teori yang dikemukakan oleh Lestari (2016), beliau menyatakan bahwa jumlah tanggungan anggota keluarga dalam suatu rumah tangga yang bersangkutan karena berhubungan dengan kebutuhannya yang semakin banyak.

\section{Implikasi kebijakan}

Berdasarkan dari penelitian ini, maka dibutuhkan suatu kebijakan guna dapat meningkatkan minat Pegawai Negeri Sipil Kota Jambi untuk menabung di bank pembambangunan daerah Jambi, kebijakan tersebut antara lain:Memperluas jaringan mesin ATM ataupun kantor ke berbagai daerah-daerah yang masih sangat jarang ATM, sehingga para masyarakat mudah untuk mengaksesnya. Serta menaikan tingkat bunga tabungan nasabah, sehingga dapat menigkatkan hasrat menabung pada PNS yang masih berada di golongan yang berpendapatan tidak tinggi.

\section{KESIMPULAN DAN SARAN}

\section{Kesimpulan}

Karakteristik sosial ekonomi nasabah Bank Pembangunan Daerah Jambi yang merupakan PNS di Kota Jambi berjenis kelamin laki-laki sebanyak 54 persen lebih mendominasi dibandingkan dengan yang berjenis kelamin perempuan yang hanya 45 persen. Dan memiliki usia rata-rata 40 tahun dengan rata-rata status perkawainan sudah menikah sebanyak 73 persen, dan merupakan tamatan dari universitas atau telah sarjana. Selain itu rata-rata pendapatan yang didapatkan para nasabah yang berkerja sebagai PNS sebesar Rp. 3.713.131 dengan jumlah tanggungan rata-rata 2 orang. Golongan PNS pada penelitian ini di bagi menjadi 3 yaitu golongan II, III, dan IV, yang mana dari hasil survey diperoleh golongan III mendominasi dengan sebesar 64 persen.

Berdasarkan hasil regresi menunjukkan bahwa variabel pendapatan, dan pendidikan tidak berpengaruh signifikan terhadap keputusan nasabah menabung pada Bank Pembangunan Daerah Jambi. Sedangkan variabel Golongan PNS, pada DK1 tidak 
berpengaruh signifikan, dan DK2 berpengaruh positif dan signifikan. Serta variabel usia, berpengaruh positif dan signifikan dan untuk variabel jumlah tanggungan berpengaruh negatif dan signifikan.

\section{Saran}

Hasil penelititan ini disarankan kepada Bank Pembangunan Daerah Jambi lebih memperhatikan pegawai negeri sipil pemerintah kota Jambi baik golongan IV ataupun golongan III dan II agar lebih tertarik untuk menabung di Bank Pembangunan Daerah Jambi dengan lebih mempromosikan aplikasi mobile bankingnya bisa melakukan CSR melalui donor darah yang untuk mempromosikan produk-produknya. Dan kepada Pegawai Negeri Sipil untuk mengurangi kebiasaan konsumtifnya, agar bisa menyisihkan pendapatannya untuk di tabung.

Penelitian ini masih jauh dari kata sempurna. Karenanya diharapkan peneliti selanjutnya menggunakan data yang lebih akurat dengan jumlah sampel yang lebih banyak, menggunakan variabel yang lebih bervaariasi, dan menggunakan metode lain yang lebih akurat dan lengkap.

\section{DAFTAR PUSTAKA}

Agresti, Alan (2007). An intodution to caterprical data analysis seconde edition. John Wiley \& Sons: New Jersey

Ahmad \& Uhbiyati. (2007). Ilmu pendidikan. Rineka Cipta: Jakarta

Amri, dkk. (2009). Metodelogi penelitian ekonomi dan penerapaannya. IPB PRESS: Jambi

Andespa, Roni. (2017). Faktor-faktor yang mempengaruhi keputusan nasabah dalam menabung di Bank Syariah. Al-Masraf: Jurnal Lembaga Keuangan dan Perbankan, 1 (2): 46 - 53

Badan Kepegawaian Daerah Jambi. (2020). Jumlah pegawai negeri sipil Kota Jambi: Jambi

BPS Kota Jambi. (2021). Jumlah penabung 2015. Diakses dalam https:/jambikota.bps.go.id. Tanggal 17 Februari 2021 Pukul 10.00 WIB

BPS Provinsi Jambi. (2021). Jumlah kantor bank status umum 2019. Diakses dalam https:/jambi.bps.go.id., Tanggal 17 Februari 2021 Pukul 12.30 WIB

D Hastuti, ME Purnawan, S Sunargo. (2019). Pengaruh variabel-variabel di sektor riil dan perbankan terhadap Shock Credit Default Swap (CDS) di Indonesia, eJournal Perdagangan Industri dan Moneter, 7 (3), 185-204

Ghozali, Imam. (2011). Aplikasi analisis multivariate dengan program SPSS. Badan Universitas Diponerogo: Semarang

Hurriyati, Ratih. (2010). Bauran pemasaran dan loyalitas konsumen. Alfabetha: Bandung

Junaidi. (2015). Model regresi binary logit (aplikasi model dengan program SPSS): Jambi

Marshel. (2013). Tingkat pendidikan, motivasi dan promosi pengaruhnya terhadap keputusan penggunaann produk nasabah priority banking Bank Sulut. Jurnal EMBA. 1 (3): 259 - 263

Maski, Ghozali. (2010). Analisis keputusan nasabah menabung: pendekatan komponen dan model logistik studi pada Bank Syariah di Malang. Journal of Indonesian Applied Economics. 4 (1): 44 - 46 
Nuswantari, Dyah. (1998). Kamus kedokteran. EGC: Jakarta

OJK. (2021). Statistik Perbankan 2018. Diakses dalam https//www.ojk.go.id/. Tanggal 29 Februari 2021 Pukul 09.00, Pukul 12.30 WIB

P.T Bank Pembangunan Daerah. (2021). Sejarah singkat bank pembangunan daerah Jambi. Diakses dalam. https:/bankjambi.co.id. Tanggal 17 Februari 2021, Pukul 12.30 WIB

PT Bank Pembangunan Dearah Jambi. (2019). Annual Report 2019: Jambi

T Yudiarti, E Emilia, C Mustika. (2018). Pengaruh utang luar negeri, tingkat suku bunga dan neraca transaksi berjalan terhadap nilai tukar Rupiah terhadap Dolar Amerika Serikat, e-Jurnal Perdagangan Industri dan Monete, 6 (1), 14-22

Widarjono, Agus. (2013). Ekonometrika. Edisi Keempat. UPP STIM YKPN: Yogyakarta 